\title{
A Simple Comment on Keynesian Economics
}

\author{
Marcus Davidsson \\ davidsson_marcus@hotmail.com
}

Accepted: December 17, 2012 Published: January 28, 2013

Doi:10.5296/jsr.v4i1.3168ＵRL: http://dx.doi.org/10.5296/jsr.v4i1.3168

\section{Abstract \\ What role does people, debt and ensemble and time averages play in macroeconomics?}

Keynesian economics (not "New Keynesian" or any other definition) was created as a direct response to the great depression in the 1930's. I agree that Keynesian economics (due to its historical and social value) should be taught to a greater extent than neoclassical economics in business schools worldwide. I will happily trade some of the mathematical sophistication of neoclassical economics for good Keynesian assumptions. However, I have some reservations to Keynes original ideas [1]. My reference on Keynes argues that he differentiate between the short run and the long run of the economy. In the short run the government should increase (decrease) government spending in a bear market (bull market) to remove the business cycle. This will result in a $+/$ - zero economy i.e. the cost of increased government spending will be offset by future tax revenues. In the long run Keynes says that we are "all dead". Hence, the long run does not matter that much. I see a problem with this type of argument. I agree that in the long run we are all dead however there will be new generations. We can't treat a country with $200-300 \%$ of GDP in debt the same as a country with $20-30 \%$ of GDP in debt in the long-run. I appreciate people that are saying; well let spend our self out of debt, when the economy bounces back we will start to collect tax revenue again (Keynesians). I agree with the fact that this generation should not have to pay for the mistake by the previous generation. I also agree with the fact that austerity does not work in the short-run! However, the question remains as to a country with $200-300 \%$ of GDP in debt will manage to get back to square 1 without writing of its debt in the long-run? Does debt ever become toxic? Are debt always good? Are all economic markets always ergodic? Samuelson [2] has written that if economists want to move economics from "history" into "science" they must impose the "ergodic hypothesis" on their theory. Keynesians and neoliberal people like Davidsson [3] has always rejected such a claim due to i.e. efficient markets theory [4]. However, not even Soros [5] believes in the efficient market theorem any more. Hansen writes "it is wholly fallacious to assume that a government can, in a private capitalist economy, spend its way out of depression"[6]. I want to extend the basic Keynes model by including debt (both national and household debt) because I think the model will become more stable (honors Keynes original theory i.e. problem solving). This would allow us to treat large impact events endogenously and not exogenously [7]. Taleb also claims that we over price equity and under price options due to the abundance of volatility in financial 


\section{Macrothink}

markets. Debt creates volatility. Debt increase leverage i.e. the arithmetic mean of $+10 \%$ and $-10 \%$ is zero $(+0.10-0.10 / 2=0)$, the arithmetic mean of $+40 \%$ and $-40 \%$ is zero $(+0.40-0.40 / 2=0)$, the geometric mean of $+10 \%$ and $-10 \%$ is $\left.\left(\left((1+0.1)^{*}(1-0.1)\right)^{\wedge} 1 / 2\right)-1\right)^{*} 100=-0.5 \%$ per round and the geometric mean of $+40 \%$ and $-40 \%$ is $\left.\left(\left((1+0.4)^{*}(1-0.4)\right)^{\wedge} 1 / 2\right)-1\right)^{*} 100=-8.34 \%$ per round. The more leverage we have the larger the difference between the arithmetic (ensemble average) and geometric mean (time average) becomes i.e. non-ergodic [8]. Also for a country with zero debt (very few exist i.e. most people are only concerned with economic growth) rich people cannot make risk-free money by buying government bonds (government debt). In such a world they will play by the same rules as poor people i.e. they need to take risk to get reward.

\section{References}

[1] Keynes (1936) The General Theory of Employment, Interest and Money

[2] Samuelson (1969) Classical and Neoclassical Theory in Monetary Theory

[3] Davidson (2009) The Keynes Solution: The Path to Global Economic Prosperity

[4] Fama (1965) Random Walks In Stock Market Prices, Financial Analysts Journal, vol 21, issue 5

[5] Soros (2005) The Fallacy of the Efficient Market Hypothesis

[6] Hansen, A and Tout H (1933) Annual Survey of Business Cycle Theory: Investment and Saving in Business Cycle Theory. Econometrica April: 119-147.

[7] Taleb (2007) The Black Swan: The Impact of the Highly Improbable

[8] Peters (2012) Economics ruling out time: http://arxiv.org/abs/1110.1578 